work at the Government Test House as well as the work of the Bureau (Delhi : Manager of Publications, 1937. 14 annas; 1s. 6d.) The Industrial Research Council is an advisory body, consisting of representatives and non-official nominees of the central, provincial and leading State Tovernments, which meets once a year to discuss policy in the co-ordination and development of research. Programmes for road research have been approved by the Council, and the development of the manufacture of casein plastics has been considered both by the Council and by the Bureau. Industrial standardization and the compilation of a list of researches in progress or contemplated in industrial laboratories are also receiving attention, and a number of prizes have been awarded by the Council for papers bearing on industrial development. The research branch of the Government Test House which deals with the research programmes suggested by the Council and other problems referred to the Bureau has completed a preliminary investigation on the characteristics which affect the setting of red lead paint. For accelerated weathering tests on various paints the weatherometer, modified to give test conditions approximately to outside weather conditions at Alipore, has been used.

SPECIAL apparatus has also been developed in India for accelerated life tests on dry cells and considerable attention has been devoted to the use of vegetable oils for internal combustion engines. A process has been developed for rendering castor oil mi cible with mineral oils of known suitability for use in such engines, and the effects of various antioxidants have been investigated. Steady progress has been made with the work of modifying the Morris and Lister engines and of equipping them with accessories to render the operating conditions fully controllable. Another section has been responsible for important investigations on the properties of petral-benzole mixtures and the effect of changes in the composition of the benzole. A number of investigations on sand, lime, surkhi, clay, etc., have been initiated. Good progress has been made with the design of the equipment for the proposed road test track at Calcutta. Separate chapters in the report deal with work on glass and on oils and soaps, the former including the improvement of glass furnaces and a survey of glass-making materials.

\section{Research in the Iron and Steel Industry}

AT the request of the Board of Trade, the Import Duties Advisory Committee has conducted an inquiry into "The Present Position and Future Development of the Iron and Steel Industry", and its report, which is full of interest, has now been issued (Cmd. 5507. London: H.M. Stationery Office, 1937. 2s. net). The report is essentially concerned with economic conditions, but its authors recognize that both the present and the future of the industry are closely bound up with scientific control and research. They express their satisfaction with the provision made for research and their hope that it will be further extended in the future. The total industrial subscription to the Iron and Steel Industrial Research Council for $1936-37$ is estimated as $£ 30,000$. As the capital of the concerns estimated to be responsible for 86 per cent of the country's output of steel in 1936 is given as $£ 126.7$ millions, this cannot be considered an excessive allowance. Several of the large steel concerns have their own research laboratories, involving a considerable expenditure, and these have actively collaborated in the investigations of the Council, thus making an indirect contribution. Full particulars of the research organization were furnished to the Committee by the Department of Scientific and Industrial Research in writing, but the seventy-three witnesses examined orally did not include a scientific metallurgist or a director of a research laboratory, and one would have welcomed a fuller appreciation in the report of the fact that the economies to be effected by scientific improvements-as, for example, in the field of refractoriesare as important as the improvements in organization to which the report, thorough as it is, is almost entirely devoted.

\section{Far Eastern Conference on Rural Hygiene}

A CoNFERENCE for Far Eastern countries on this subject was opened on August 3 by the GovernorGeneral at Bandoeng, Java. This Conference was arranged by the League of Nations Health Organisation under the presidency of Dr. T. Offringa, director of the Netherlands Indies Public Health Service, with Dr. J. Rajchman, medical director of the League Health Committee, as secretary, assisted by Dr. C. L. Park, director of the Eastern Bureau of the Health Organisation. The Conference is meeting in five sections, in which the following subjects will be discussed: ( 1 ) health and medical services: the advantages and disadvantages of training 'semiqualified' or assistant doctors to assist the qualified medical staff, and possible alternatives; (2) rural reconstruction and collaboration of the population, with the view of improving conditions of life in rural districts, a policy favoured by the Government of India and other countries; (3) sanitation and sanitary engineering, including housing, water supply, latrines, refuse disposal and fly control ; (4) nutrition, a subject of importance in the East, for it has been estimated that 75 per cent of the population of Asiatic countries exist on a diet below the standards fixed by European science; (5) measures necessary to combat specific diseases, such as malaria, plague, tuberculosis, hookworm infection, yaws and leprosy, and mental diseases; also drug addiction.

\section{The Science Museum}

BesIdes the usual statistical information regard. ing the number of visitors and attendances at lectures, notes on special exhibitions, on acquisitions and the progress of the five main divisions of the Museum, the annual report of the Advisory Council of the Science Museum for 1936 is of especial interest as it contains a review of the growth and activities 
of the Library, which is being developed as a National Library of Science. During the year, the Library was used by 22,000 readers, while the issues on loan of books and periodicals to Government departments, scientific and technical societies, colleges, etc., was 21,000. The Library receives more than 9,000 current periodicals and the contents of these are all indexed, references to these and to other matters now running into millions. There are about 250,000 books in the Library. "The two main functions of the Library," the report says, "may broadly be stated as the acquiring of documents and making them readily available", the latter consisting of cataloguing the volumes, maintaining indexes of their contents, provision of the volumes to readers, loan service, supply of bibliographies, supply of photostat copies, and Library publications. There have been many valuable additions to the collections in the Museum, and during the year under review special exhibitions were arranged illustrating the progress of research at very low temperatures, the scientific aspects of smoke pollution of the atmosphere and the developments in electric illumination.

\section{Overhead Costs in Business Management}

ONE of the most difficult tasks for a business management, whether the concern be large or small, is the adequate control of overhead costs. The usual classification of overhead expenses into salaries, rent, rates and taxes, legal expenses or the like is quite inadequate, because responsibilities cannot be tied up with the expenditure on these items, and generally there is no method of measuring the value obtained from the expenditure. In a valuable and thoughtprovoking report entitled "The Control of Overheads" (Mansfield House, 376 Strand, W.C.2. 5s.), prepared by a committee of the Management Research Groups, the subject is examined with the aim of securing effective control through localization of responsibility. To secure this, the report recommends the division of all overhead expenditure into a series of functions or services, each of which would be in charge of one person, thus permitting the fixation of responsibility. In order to assess the value of the work done by each section of the organization, its cost must be related to the volume of the work done and to the value or quality of that work; and for this purpose various ratios or 'yard sticks' are suggested in the report. The essential requirement is that responsibility for functional costs should be invested in persons, and to ensure that personnel shall cover each of the functions, it is most desirable that an organization chart should be constructed. Budgetary control is an excellent method of reviewing expenses in advance and making comparisons immediately results are available. Costs, however, may be rendered useless as a means of measuring efficiency because of plant working under capacity owing to insufficiency of orders. The report, therefore, recommends that the costs be 'purified' of the cost of idle plant by the abstracting and debiting of all such expenses to a non-productive account, which is carried straight on the trading account.

\section{Economics of Wages and Price Levels}

IN an address before the Economic Reform Club, London, on June 30, entitled "The Economic Reforms Required for Lasting Prosperity and Peace" which has now been issued in pamphlet form (Economic Reform Club, 61 Great Cumberland Place, London, W.1. 9d.), Mr. A. G. McGregor stresses the supreme importance of reform in wages regulation in securing a steady purchasing power of the pound. Heurges that the method of adjusting wages by industrial dispute should be abolished and replaced by direct government control to adjust wages in accordance with the price level. This would in the first instance involve raising wages and salaries to a level which would bring consuming power in step with productive power, and thereafter the wages board would maintain the proper relation between wages and price level. He stresses the point that bankers should be relieved of all responsibility over the general price level and outlines the functions of a rational banking policy designed to accommodate industry and com. merce with the necessary funds but under rules which eliminate any monetary influence on the price level. He contends that if wages and salaries are controlled in the way indicated so as to secure a satisfactory equilibrium between consuming power and productive power, economic liberty is no more affected than individual freedom in general by the ordinary government responsibility for maintaining law and order, and also that the higher wages and internal consuming power would assist the export trade.

\section{Purchasing Power with a Managed Gold Standard}

In a pamphlet entitled "A Managed Gold Standard" (W. Heffer and Sons, Ltd., Cambridge), E. A. Moyer urges that unemployment and economic distress are due to lack of purchasing power. The State's lack of purchasing power has necessitated higher taxes, which have further decreased the citizen's purchasing power. This lack of purchasing power is due to lack of counters, or money, used for exchanging one man's labour for another's, caused by the inability of an inflexible money standard to keep pace with a continuous rise in prices. He advocates accordingly a managed gold standard based on the monopoliza. tion by the State of the note issuing bank of the standard (gold), and the fixation of the standard's money value by an international commission which should revise this value periodically according to the need of the world's productive ability to ensure the standard's flexibility. The managed standard will instantly increase the purchasing power of the State by increasing its right to issue counters without risk of devaluation, and this increased purchasing power by permitting decreased taxation will increase the purchasing power of the citizen as well as thus stimulating industrial and commercial prosperity. Unemployment will be further diminished or elim. inated by the increased ability of the State to initiate public works. The managed gold standard could be introduced if a few countries only agreed to do so, since other countries would be bound to follow. 